\title{
EMPLOYMENT CHANGE IN MANUFACTURING AUSTRALIA vs NEW ZEALAND 1987-1992
}

\author{
Richard Willis \\ Victoria University of Wellington
}

Interest in the comparisons between the economic policies of Australia and New Zealand recently reached fever pitch as the Victoria Labour Party sought to fight its 1992 state election by pointing out the consequences of its oppositions more-market policies, using the alleged disastrous results of such policies in New Zealand in an attempt to persuade voters. It is by now part of folk history that the New Zealand Prime Minister responded with an attack on the state of the Victoria premier's physical persona. Behind these political cheap shots lies a deeper story of the ways in which employment has changed in both countries both in terms of numbers of jobs being created and lost and the conditions of employment. It is well known that Australians are especially concerned about the replication of New Zealand's employment contracts legislation in their country, but this subject falls outside the competence or scope of this paper. Unemployment in both countries climbed over 11 per cent in 1992 (Management 1992) though New Zealand's rise in the unemployment stakes has been more dramatic having come from a figure of only $2.2 \%$ in 1980 compared with Australia's 5.9 (OECD: 1992).

In New Zealand's case it is clear that most of the net job loss has come from a decline in Manufacturing employment. The release of the 1991 Business Activity Statistics showed that there was a total net job loss of 77,176 jobs between 1987 and 1992. Manufacturing contributed 60.649 or 78.6\% of this net loss (Department of Statistics: 1992). In the light of this dramatic contraction of New Zcaland's manufacturing employment in the last five years the purpose of this paper is to compare changes in manulactunng employment in the two countries against the diflerent policy background and environments.

\section{Country Differences}

Table 1 presents the basic physical, economic, and soc tal geography of the two countries using the latest OECD data available. It shows that New Zealand has only $3.5 \%$ of Australia's land, $19.8 \%$ of its population and $18.7 \%$ of its labour force: Australia is more wealthy less taxed and produces more energy.

Looking more specifically at the Manufacturing Sector it is clear that it plays a similar role in both countries, contributing around $25 \%$ of employment (OECD definition), significantly more to GDP in Australia than in New Zealand, and a major contribution to exports in both countries (see Table Two).

Table 1. Australia and New Zealand: basic comparisons

$\begin{array}{lrrr}\text { Item } & \text { Australia } & \text { New Zealand } & \text { NZ as \% of } \\ \text { Total Area (000 sq kms) } & 7686.8 & 268.7 & 3.5 \\ \text { Population (1990) } & 17.08 \mathrm{~m} & 3.38 & 19.8 \\ \text { Growth Rate (1989/90) } & 1.5 \% & 1.1 \% & 73.3 \\ \text { \% under 15 years } & 21.9 & 23.0 & 105 \\ \text { 15-64 years } & 66.9 & 66.1 & 98.8 \\ \text { 65+ years } & 11.2 & 10.9 & 97.3 \\ \text { Total Labour Force (1990) } & 8509 & 1596 & 18.7 \\ \text { \% Primary } & 5.6 & 10.6 & 189 \\ \text { \% Industry } & 25.4 & 24.6 & 96.8 \\ \text { \% Services } & 69.0 & 64.8 & 93.9 \\ \text { Disputes (per 000 person days) } & 1376 & 331 & 24.0 \\ \text { Self Employment \% } & 15.0 & 20.2 & 134.6 \\ \text { GDP per capita (1990) } & 17282 & 12656 & 73.2 \\ \text { Total tax\% GDP(1990) } & 30.1 & 39.4 & 129.5 \\ \text { Total energy/capital (1990) } & 9.3 & 3.40 & 36.5\end{array}$


Item

\% Labour force

$\%$ contribution to the Labour force

$\%$ Contribution to GDP)

\% Contribution to Exports
Food,Bev. \& Tobacco
Textiles
Clothing \& Footwear
Wood \& Furniture
Paper \& Printing
Chemicals, Petrol \& Coal
Non M.M.
Basic Metals
Fab.Metal Products
Transport Equiptment
Machinery
Other

Total
Australia

25.4

19.2

$31.0^{2}$

$\begin{array}{rc}\text { (1989) } & \begin{array}{c}\text { \% Manuf. } \\ \text { Exports }\end{array} \\ 14.0 & 25.5 \\ 3.0 & 5.5 \\ 0.2 & 0.4 \\ 1.1 & 2.0 \\ 0.6 & 1.1 \\ 4.5 & 8.2 \\ 0.3 & 0.5 \\ 20.9 & 38.1 \\ 1.2 & 2.0 \\ 2.4 & 4.4 \\ 5.1 & 9.3 \\ 1.4 & 2.6\end{array}$

New Zealand

24.6

$20.1^{1}$

26.7

\% Manuf.
Exports
8.6
4.0
6.3
9.7
5.7
12.9
0.9
23.0
3.7
1.4
10.3
12.0

$54.9 \%$

(1991)

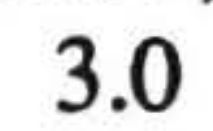

1.4

2.2

3.4

2.0

4.5

0.3

8.0

1.3

0.5

3.6

4.2

$34.8 \%$

Source: Australian \& NZ Yearbooks 1991 Employment in Manufacturing - the basic data

Notes: 1. NZ Business Activity 1991

2. Includes sewage services

3. OECD 1989

The other salient fact to emerge from this table is that when the data sets for manufactured exports are unscrambled, Australia's manufactured exports make up a more significant percentage of total (54.9\%) than do New Zealand's (74.8\%). This difference may be in part explained by the different years chosen and available for each country. What is however interesting is that there are strong similarities in the major contributing groups; food, chemicals, base metals, and some differences e.g. New Zealand stronger in clothing and wood products.

Tables three and four set out the basic data on employment change in manufacturing in Australia and New Zealand 1987-1991. What is immediately clear is that the overall loss of manufacturing jobs has been much more dramatic in New Zealand (- $20.4 \%$ compared to Australia's $5.9 \%$ ), furthermore in Australia only three industrial groups declined by over $10 \%$ (textiles, clothing and footwear and transport equipment) where in New Zealand only two sectors (Base Metals and Paper \& Printing) declined by less than $10 \%$.

The other interesting feature is the size of contribution made to total employment by each sector in the different countries. Of the twelve industry groups listed the top half (food to chemicals) are larger percentage contributors in New Zealand where the bottom half (Non Metallic minerals to other manufacturing) are larger contributors to Australian manufacturing employment. New Zealand for example has $25.5 \%$ of its employment in food beverages and tobacco compared with Australia's 17\%, while Australia has $39.1 \%$ in Non Metallic Minerals, metals and machinery compared with New Zealand's $31.8 \%$.

\section{Regional Change}

Table five compares trends in manufacturing employment for New Zealand regions and Australian States. The first point to be made is that differences among regions vary more markedly in Australia if the smaller Australian Capital Territory figure is included. (33.2 percentage points from highest to lowest compared to New Zealand's 21.4). If the worst performing regions are disregarded for both countries the percentage differences between highest and lowest regions becomes more even (19.3 for Australia compared with 19.9 for New Zealand). Both countries also display marked regional concentration of manufacturing employment with over 80 per cent of all industrial jobs in Victoria New south Wales and Queensland, while in New Zealand the four largest populations centres make up 67.5 per cent of industrial jobs. Interesting too is the fact that changes have taken place in the importance of different states and regions: in Australia New South Wales has taken over from Victoria as the most important state for manufacturing employment. 
Table 3. Changes in New Zealand Manufacturing Employment 1987-1991

$\begin{array}{lrrrrr} & 1987 & 1991 & \begin{array}{c}\text { \% change } \\ 1987-91\end{array} & \begin{array}{c}\text { \% total } \\ \text { Manuf.1991 }\end{array} & \begin{array}{c}\text { Output per } \\ \text { worker 1989 } \\ \text { \$NZ }\end{array} \\ & & & & & \\ \text { Food, Bev's \& Tobacco } & 73,361 & 60,881 & -17.0 & 25.5 & 354,723 \\ \text { Textiles } & 13,988 & 10,205 & -27.0 & 4.3 & 122,347 \\ \text { Clothing \& footwear } & 26,862 & 18,209 & -32.2 & 7.6 & 74,415 \\ \text { Wood \& Furniture } & 26,560 & 21,721 & -18.2 & 8.1 & 102,391 \\ \text { Paper \& Printing } & 29,915 & 21,113 & -9.4 & 11.3 & 229,7651 \\ \text { Chemicals Petrol \& Coal } & 25,713 & 20,464 & -20.4 & 8.6 & 314,841 \\ \text { Non Metallic minerals } & 9,708 & 6,306 & -35.0 & 2.6 & 163,876 \\ \text { Base Metals } & 6,599 & 6,665 & +1.0 & 2.8 & 208,795 \\ \text { Fab.Metal Products } & 27,446 & 20,895 & -23.9 & 8.7 & 117,664 \\ \text { Transport Equip. } & 21,382 & 14,644 & -31.5 & 6.1 & 144,918 \\ \text { Machinery \& Equip. } & 33,790 & 27,817 & -17.7 & 11.6 & 107,417 \\ \text { Other Manuf. } & 4,739 & 4,002 & -15.6 & 1.7 & 93,443 \\ & & & & & \\ \text { Total } & 300,063 & 238,922 & -20.4 & 100.0 & 169,549\end{array}$

Source: Business Activity Statistics 1987-1991

In New Zealand Auckland and Wellington's share's of total manufacturing employment have decreased whereas Waikato's and Canterbury's have increased.

\section{Changes in labour productivity}

In 1982 Hall produced data to show that output per worker was basically half that of Australia for manufacturing in New Zealand if the data were converted to common currency using the exchange rate of the time. In this paper he asked the opinion of several leading economists as to the meaning of what he found. Johnson of the Business Statistics Division, Department of Statistics claimed that the measure "was a reasonable estimate of labour productivity". Weatherston, economist at the Manufacturers Federation concluded that the simple measure said little about the competitiveness of capital but conceded 'if it were a true measure then New Zealand would get creamed'. Tarrant of the New Zealand Industries Development Commission said he was not surprised at NewZealand's low competitiveness, and said over manning was a major problem for New Zealand citing New Zealand Railways as an example. Bevan, economist with the Federation of Labour noted the lack of a measure of capital inputs, of the relative prices and wages in the two countries and also said the different approaches to subsidies needed to be built into the analysis. (All quotes from Hall, 1982).

\section{Table 4. Changes in Australian Manufacturing Employment 1987-1991}

$\begin{array}{lrrrrr} & 1987 & 1991 & \begin{array}{c}\text { \% Change } \\ 1987-1991\end{array} & \begin{array}{r}\text { \% Total } \\ \text { Manuf.1991 }\end{array} & \begin{array}{c}\text { Output per } \\ \text { worker 1989 } \\ \text { \$Aus }\end{array} \\ \text { Food Bev \& Tobacco } & 168,800 & 170,700 & +1 & 17.7 & 174,400 \\ \text { Textiles } & 34,500 & 28,700 & -16.8 & 3.0 & 127,200 \\ \text { Clothing \& Footwear } & 74,400 & 56,000 & -24.7 & 5.8 & 70,500 \\ \text { Wood \& Furniture } & 76,000 & 75,700 & -0.4 & 7.8 & 93,500 \\ \text { Paper \& Printing } & 107,100 & 103,700 & -3.2 & 10.7 & 119,200 \\ \text { Chems, Petrol \& Coal } & 53,700 & 53,000 & -1.3 & 5.5 & 259,200 \\ \text { Non M.M. } & 38,900 & 39,600 & +1.8 & 4.1 & 171,700 \\ \text { Base Metals } & 73,500 & 68,100 & -7.3 & 7.1 & 274,300 \\ \text { Fab.Metal Products } & 97,400 & 96,600 & -0.8 & 10.0 & 111,000 \\ \text { Transport Equipt. } & 128,200 & 123,600 & -3.6 & 12.8 & 110,500 \\ \text { Other Manuf. } & 60,700 & 59,900 & -1.3 & 6.2 & 123,200 \\ \text { Total } & & & & & 141,600\end{array}$

Source: ABS Census of Manufacturing Establishments. 
Table 5.Regional Change in Manufacturing Employment 1987-1991

\author{
New Zealand Regions \\ Share $1991 \%$ change 1987-91
}

$\begin{array}{lrr}\text { Northland } & 2.0 & -28.1 \\ \text { Auckland } & 35.4 & -21.8 \\ \text { Waikato } & 8.5 & -8.5 \\ \text { Bay of Plenty } & 4.8 & -18.7 \\ \text { Gisborne } & 1.0 & -28.4 \\ \text { Hawkes Bay } & 4.4 & -16.3 \\ \text { Taranaki } & 3.1 & -17.9 \\ \text { Manawatu } & 5.8 & -20.8 \\ \text { Wellington } & 9.5 & -25.3 \\ \text { North Island } & 74.4 & -20.5 \\ \text { Nelson/Marl. } & 2.9 & -4.5 \\ \text { W.Coast } & 0.6 & -28.3 \\ \text { Canterbury } & 14.1 & -18.9 \\ \text { Otago } & 4.2 & -29.9 \\ \text { Southland } & 3.6 & -19.1 \\ \text { South Island } & 25.6 & -19.9 \\ & & \\ \text { New Zealand } & 100.0 & -20.3\end{array}$

Source: Department of Statistics, 1992

What is interesting is how this low level of output per worker has changed. Table Six shows changes in output per worker $1978-79$ to $1988 / 8$.

These data are not adjusted from exchange rates because it is believed the falling New Zealand dollar would distort the domestic situation in each country. Nevertheless the percentage change in New Zealand (coming off a lower base) can be seen to be almost double that for Australia, and this is consistent with the lower rates of job loss in Australian manufacturing. It is now necessary to place these statistical trends against the different policy environment background.

\section{The Policy Environments: a comparison.}

In both Australia and New Zealand the history of industrial policy has been the debate between protection and free

Table 6 Output per worker $1978 / 79$ to 1988/89

\begin{tabular}{lll}
\multicolumn{2}{c}{ \$New Zealand } & \$Australia \\
$1978 / 79$ & $\$ 36,622$ & $\$ 47,941$ \\
$1983 / 84$ & $\$ 76,202$ & $\$ 84,600$ \\
$1988 / 89$ & $\$ 169,549$ & $\$ 139,650$ \\
& & \\
\% change & & \\
$1978 / 79$ to & & \\
$1988 / 89$ & $+363 \%$ & $+191 \%$
\end{tabular}

Sources: Department of Statistics 1979, Department of Statistics 1992, Australian Bureau of Statistics 1992
Australian States

Share $1991 \quad \%$ change 1987-91

$\begin{array}{lrr}\text { NSW } & 34.4 & -7.8 \\ \text { Victoria } & 32.8 & -11.4 \\ \text { Queensland } & 13.0 & +6.4 \\ \text { S.Aust. } & 9.8 & +4.3 \\ \text { W.Aust. } & 6.8 & -6.0 \\ \text { Tasmania } & 2.6 & +3.3 \\ \text { North.T } & 0.3 & +6.9 \\ \text { ACT } & 0.3 & -26.8 \\ \text { Australia } & & -5.9\end{array}$

trade with minor different emphasis in the two countries. The dependence of both countries on primary exports meant that the primary aim of protection was first "to create a substantial manufacturing industry so as to provide a more balanced and sophisticated economy" (Stanford:1992:37). In New Zealand's case the emphasis was equally on providing jobs and saving foreign exchange such as in the 1930s when import licensing was introduced. In both countries it is fair to say that for most of their history the protectionists won out over the freetraders such that as chart one shows both had very high levels of protection compared to their OECD counterparts in the 1970s, Figure one.

Figure one introduces the difficult issue of how New Zealand's rate of protection varies from that of Australia and indeed comparisons with other countries. The recent study by Duncan Lattimore and Bollard (1992) shows the complexity of this subject and illustrates that the conclusions reached depend very much upon which measure is used. The selection of tables taken from the above publication illustrates this point, although the magnitude of the differences between Australia and New Zealand is reasonably consistent (see Table 7).

What becomes clear is that despite the greater publicity given to restructuring and deregulation in New Zealand manufacturing sector our overall level of industrial protection still remains higher than that of Australia, even making allowance for technical debates about the effectiveness of different measures.

The simple but important conclusion arising from this analysis is that the removal of protection began much 


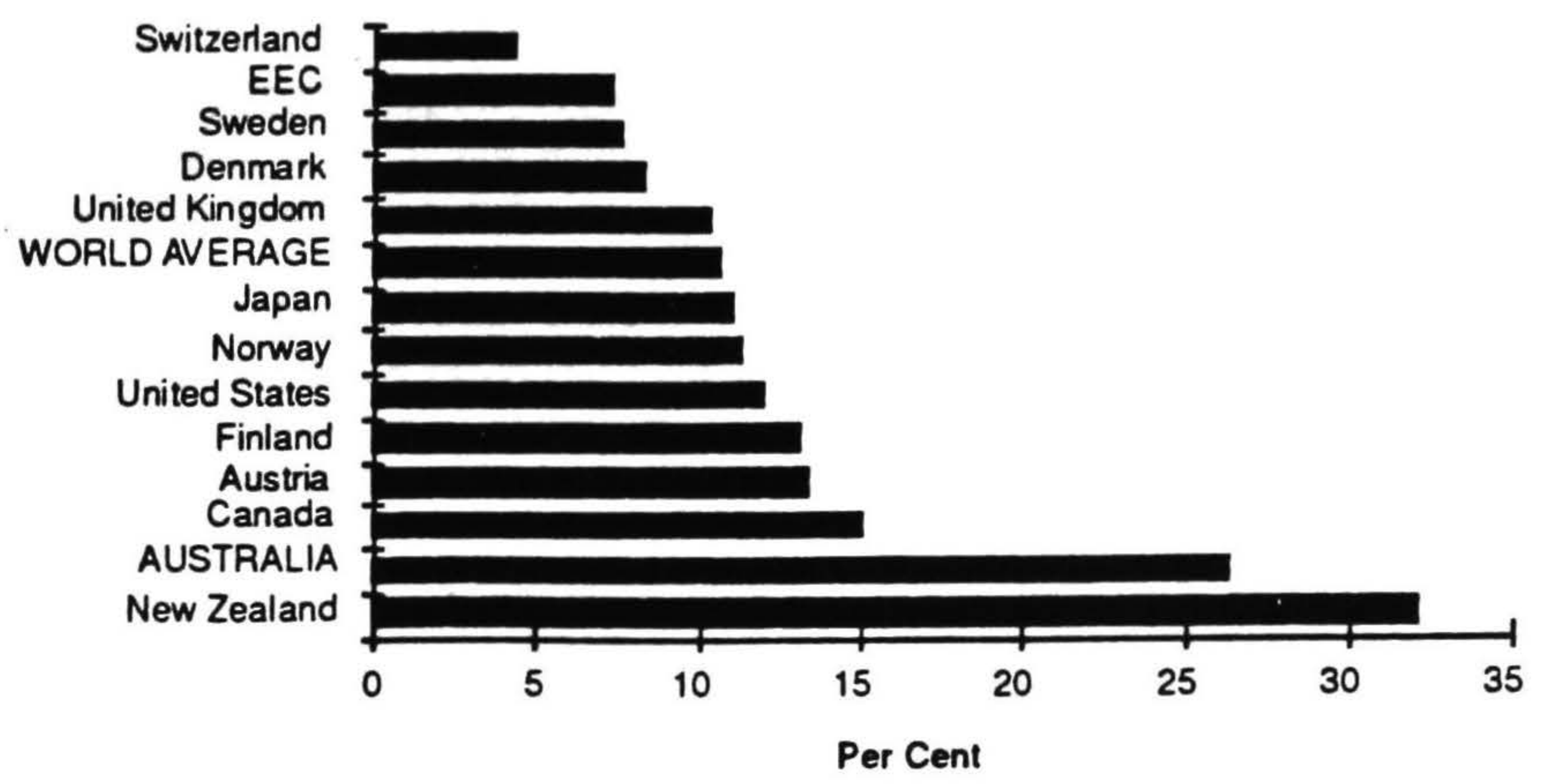

Source: GATT, as reproduced in Stanford (ed) 1992

\section{Table 7. Comparison of Selected Measures of Protection}

\section{Measure}

Items free of tariffs (1987) \%

Items below 15\% (1987) \%

Average levels of Industry Tariffs

Dutiable

(mid-1980s ) Total

Effective rates of Assistance

for Manufacturing 1981/82

$\begin{array}{llll} & 1989 / 90 & 16 \% & 19 \% \\ \text { Metal Products } & 1981 / 82 & 31 \% & 69 \% \\ & 1989 / 90 & 18 \% & 34 \%\end{array}$

Source: Duncan Lattimore \& Bollard (1992)

earlier in Australia, that the process of structural adjustment has been more gradual and firms have had a longer time to adjust to new policy environments. For example import licensing as a major protectionist measure was abolished nearly 20 years earlier in Australia than it was in New Zealand. This has contributed to the kind of 'stored up effect' of postponing change in manufacturing which happened in New Zealand. This becomes clear when a longer term view of employment changes is taken for both countries (see Table 8).

It is clear for example that between 1971 and 1986 the loss of employment in Australia was 19\% compared with an addition of over $6 \%$ for New Zealand. In fact as Table Eight shows the cumulative percentage loss over the 20 year period is much greater for Australia 26.2\% compared with $15.6 \%$ for New Zealand. The difference comes in the rapidity and severity of manufacturing job loss in New Zealand in the last five years. The analogy of different forms of treatment for drug addiction is almost appropriate. In one sense Australia has gone through a gradual withdrawal treatment over 20 years with the substitution of alternative methodone doses of intervention from time to time as the politics of free trade and protection have waxed the 'cold turkey' quick but violent withdrawal treatment. The real concern is that the treatment may be worse than the disease, such has been the loss of investment output and employment in manufacturing in the last five years.

This contrast is also reflected in the kinds of advice being received by respective governments. In New Zealand since 1984 there has been a consistent monetarist, level playing field deregulation lobby from Treasury and business leaders along with rather muted opposition from radical

Table 8. Longer Term Employment Change in Australian and New Zealand Manufacturing 1971-1991

Full-time

equivalents

Australia

New Zealand

(In ' 000)

1971

1304

\% change 1971-76

$-8.3 \%$

282

1976

1195

\% change 1976-81

$-1.3 \%$

$-0.6 \%$

1981

1180

\% change 1981-86

$-13.1 \%$

306

$-2.0 \%$

1986

1052

300

\% change 1986-91

$-8.4 \%$

$-20.6 \%$

1991

963

238

\% change 1971-91 - $-26.2 \%$

$-15.6 \%$ and wanted. New Zealand on the other hand has opted for

Sources: Australia- A.B.S. Yearbook 1991

New Zealand - Philpott 1990 
economists and trade unions. Rogernomics was quickly followed by the more market policies of Ruth Richardson and the Bolger government. In Australia the signals have been more mixed. On the one hand the March 1991 economic statement crystalised advice from the level playing field school of thought which had dominated government thinking during the 1980s (Australia, Deputy Prime Minister 1991). But by contrast the Papas Carter Report (Australian Manufacturing Council 1990) rejected the low tariff or no tariff option, recommending continuation of "carefully phased reductions in protection with the timing dependent on the success of other industry policies designed to foster industrial restructuring and increased competitiveness" (Fagan 1991). This report was interventionist based on the global economy, the role of State policies,and widespread forms of non-tariff protection.

\section{Summary and Conclusions}

The above analysis has shown that job loss in New Zealand's manufacturing sector in the last five years has been far more dramatic and severe than the equivalent Australian figure. However despite this the New Zealand manufacturing sector remains slightly more protected than its Australian counterpart. The paper has also demonstrated that Australian industry's job loss has been greater over the long term for example the last 20 year period and that the Australian manufacturing firms have had longer to adjust and change, and that the political and policy debate about free trade versus intervention has been more intense than has hitherto been the case in New Zealand.

\section{Future Research}

Levels of protection have profound implications for the demand for domestic labour. By relaxing effective rates of protection so foreign workersbecome competitors to domestic workers. We know little about the exact ways in which changes in New Zealand or Australian protection have affected the labour markets of each country. This paper has scratched the surface. Two areas merit closer attention: firstly the way in which competition in particular product markets impacts on the labour adjustment practices of the firms involved and secondly, the way in which domestic production itself has been altered in order to either avoid competition from overseas or to compete on foreign markets and labour implications of this.

\section{References}

Australian Bureau of Statistics 1992 Manufacturing Industry Australia 1990-91 (June).

Australia. Department of Prime Minister and Cabinet 1991Building a Competitive Australia Govemment Publishing Service.
Australian Manufacturing Council 1990)The global challenge: Australian manufacturing in the 1990s (The Pappas Carter Report)

Department of Statistics 1979 Occasional Paper 3 A Comparison of New Zealand and Australian Manufacturing Industries 1978/79.

Department of Statistics 1992)Business Activity 1991

Duncan, I, Lattimore R \& Ballard, A 1992 Dismantling the Barriers: TariffPolicy in New Zealand. NZIER Research Monograph 57.

Fagan, R H 1991 'Industry Policy and the MacroEconomic Environment', Australian Geographer 22:2: 102-104.

Management 1992 September Vo. 39 No. 8.

OECD 1992) Statistics on member Countries.

Philpott, B 1990 A Consistent data base of Sectoral Employment 1950-1990. R.P.E.P. Internal Paper: 223 Victoria University.

Stanford, J (ed) 1992 Industrial policy in Australia and Europe. Department of Industry, Technology and Commerce. Australian Government Publishing Services, Canberra 